\title{
New Theory for A Conceptual Framework towards Audience Delight
}

Hussain, S. A. S and Rozi, Q. M.

To Link this Article: http://dx.doi.org/10.6007/IJARBSS/v11-i5/9941

DOI:10.6007/IJARBSS/v11-i5/9941

Received: 02 April 2021, Revised: 26 April 2021, Accepted: 10 May 2021

Published Online: 29 May 2021

In-Text Citation: (Hussain \& Rozi, 2021)

To Cite this Article: Hussain, S. A. S., \& Rozi, Q. M. (2021). New Theory for A Conceptual Framework towards Audience Delight. International Journal of Academic Research in Business and Social Sciences, 11(5), 468480.

Copyright: (c) 2021 The Author(s)

Published by Human Resource Management Academic Research Society (www.hrmars.com)

This article is published under the Creative Commons Attribution (CC BY 4.0) license. Anyone may reproduce, distribute, translate and create derivative works of this article (for both commercial and non-commercial purposes), subject to full attribution to the original publication and authors. The full terms of this license may be seen at: http://creativecommons.org/licences/by/4.0/legalcode

Vol. 11, No. 5, 2021, Pg. 468 - 480

http://hrmars.com/index.php/pages/detail/IJARBSS

Full Terms \& Conditions of access and use can be found at http://hrmars.com/index.php/pages/detail/publication-ethics 


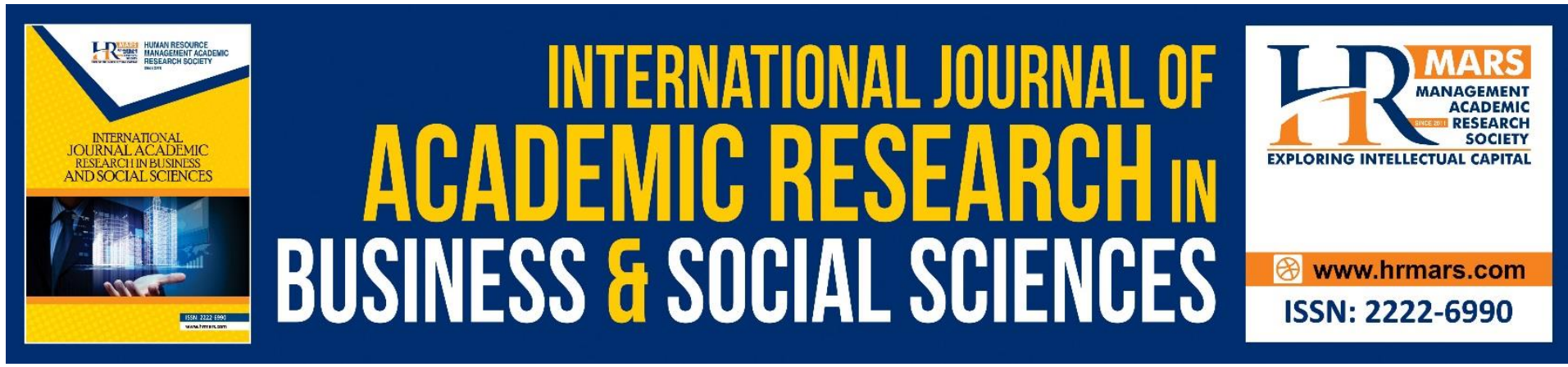

\title{
New Theory for A Conceptual Framework towards Audience Delight
}

\author{
Hussain, S. A. S and Rozi, Q. M. \\ Universiti Malaysia Sarawak.
}

\begin{abstract}
Countries has developed strategies to attract tourists in order for them to experience, visit, engage and participate in a touristic product or service. The brand has become a trend in marketing and considered a medium for increasing product and services demand. Festival can have managed as a brand, where it is seen as a tourism product. The existence of festivals helps develop the tourism industry to enhance the economic sector and provide the best travel experience to visitors. In early 2020, the event industry has been affected by the pandemic covid-19 because the government banned gathering and cancelled events worldwide (Nilsson, 2020). As a result of this pandemic, the event industry needs to reevaluate how they conduct events. Some firm takes other initiatives by running event virtually. This paper focuses on developing a conceptual framework for the audience delight in a virtual arts festival. The arts festival brand focuses on data collection medium in analysing the audience's delight through the experience and personality felt.
\end{abstract}

Keywords: Brand Experience, Sensory, Affective, Cognitive, Behavioural, Brand Personality, Audience Delight.

\section{Introduction}

Understanding that delight affect loyalty is essential for the product and service, it includes all sectors that engage the audience in carrying out activities such as tourism, hospitality, and event. Delight is an emotional response that affects the audience. This study focuses on the importance of arousing the inner delight of the audience towards a brand. It will lead to the organiser's awareness that brand experience and personality help them improve the quality of service and management and provide them with new information and opportunities to enhance audience delighted. With a high percentage of the audience delight, it can influence audience behaviour and automatically impact returning intentions.

\section{Literature Review}

A brand is known as the name that describes a product. In this perspective, the brand used by the researcher is a festival. In the tourism sector, the festival is used as a brand to attract spectators to attend the event, and the same can help increase and introduce the name to a higher level. The brand involves the existence of names and symbols that are different from other organisations. Each product has its distinctive features; therefore, they require a brand to facilitate audiences to identify and be interested in the product they produce. Brands are 
an essential part of marketing to expand and introduce the product. Chernev (2017) states that brands are extensive, and a brand's purpose is to evoke meaningful association in people's minds. Audience delight is a powerful medium in a festival brand, where it has a positive effect on audience loyalty compared to satisfaction (Loureiro, 2010). In consonance with Meyer, Barnes, and Friend (2017) stated that although satisfaction and delight bring positive effects to the audience, only delight leads to future intentions. Experience is the result of brand usage depending on the position and meaning conveyed by the same brand itself, and that may explain why users decide to create and maintain relationships with one or more specific brands (Chaney, Lunardo, and Mencarelli, 2018). Brand experience creates and develops a trust-based communication platform between brands and audience. Brand experience is a high level of familiarity with particular subjects, stemming from inclusive activity (Ahn and Joon, 2018). With the existence of a brand experience, the audience will develop their view about the brand and at the same time help them express the personality.

\section{Research Conceptual Framework}

A conceptual framework is a set of ideas or theories related to how a particular phenomenon works or relates to its parts (Svinicki, 2010). Research conceptual framework is a direction and guide in conducting research. It is structured in a logical structure to help provide an overview or visual display of how ideas in study interrelated (Grant \& Osanloo, 2014). The development of this conceptual framework helps identify broader views and information about audience enjoyment. This study provides an approach and emphasises the importance of 'delight' in a brand to influence the audience's actions. This conceptual framework helps researchers develop questions in collecting qualitative and quantitative data to ensure that the study's objectives can be achieved.

\section{Findings}

The conceptual framework represents the researcher references of brand and delight of the audience in the festival scope. There is three central part outlined in this conceptual framework; it is the independent variable, moderated and dependent variable. This conceptual framework presents the brand experience as an independent variable, brand personality as a moderator and delight as a dependent variable.

\section{A. Brand Experience}

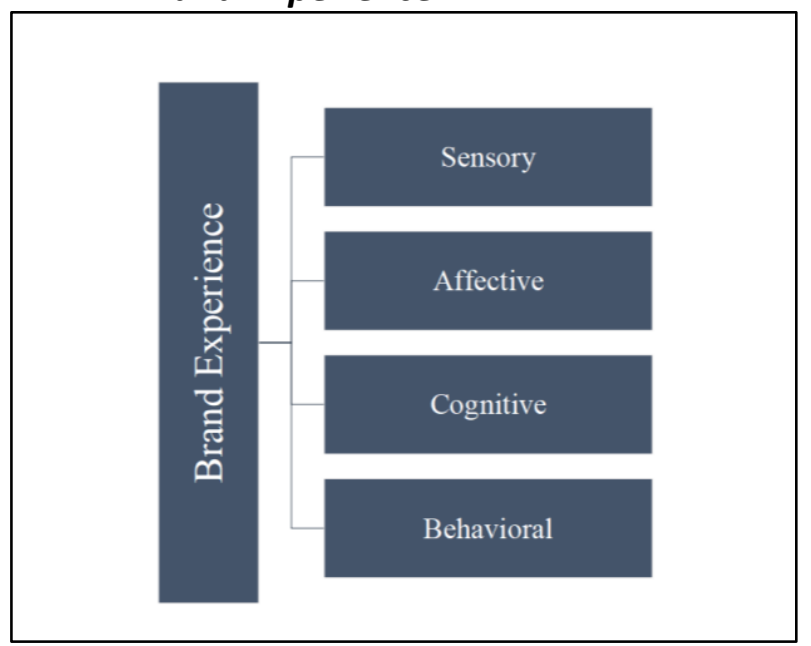

Figure 1: Items of Independent Variables

Sources: Brakus, Schmitt and Zarantonello (2007), Ong, Lee and Ramayah (2018) 
Experience is related to what happens or goes through a person in their life. Experience can be associated with the memory, senses and feelings of the individual, which makes them feel, remember and even think about it when in contact with the environment (media, education, family, employment); experience can see as something practical, it can obtain by a person based on a particular profile. Brakus, Schmitt and Zarantonello (2009) stated that experiences arise in various situations, directly or indirectly. Experience directly occurs during the purchase and use of a product or service, while indirectly occurs when users are exposed to media (advertising, websites), marketing such as promotion, communication, etc. Berridge (2009) argues that experience controls the daily consumption of goods and services in various fields (health, entertainment, marketing, and travel). Beneficial and exciting experience can create delights in the audience where it directly affects emotions and behaviour.

Brand experience is a response created by brand-related stimuli such as brand prestige (Choi, Ok, and Hyun, 2017), brand design and brand identity (Brakus, Schmitt, and Zarantonello, 2009). Brands and audiences are a complementary union. The use of the brand will create a unique experience for the audience and lead to repetition of the purchase, directly and indirectly influencing people to involve the brand in their lifestyle. Everyone has their lifestyle and use of their brand-appropriate and reflects their personality. Wulandari (2016) defined brand experience as the audience's perception based on its relationship with the brand. Several previous researchers have discussed brand experience dimensions (Brakus, Zarantonello and Schmitt, 2007; Nyeven, Pedersan and Skard, 2012; Hulten, 2010; Iglesis, Singh and Foguet, 2010). The brand experience dimension is divided into four; sensory, affective, cognitive and behaviour.

\section{i. Sensory}

Senses dimension are one of the most critical factors in conveying the experience to the user. The senses are associated with the five senses; sight, sound, smell, touch and taste (Brakus, Zarantonello and Schmitt; 2007, Hulten; 2011, Lindstrom; 2005, Ditoiu and Caruntu; 2014). Sensory is about how brand sometimes smells, taste and feel. This is what makes a particular brand is fell tangible and real. Besides, those senses give the audience the ability to identify and categorise brands based on a sensation as a decisive edge. According to Hulten (2011), one of the sensory strategies is to differentiate brands; through sensors, brands can reach the minds and senses of the audience from a cognitive and emotional point of view. Sensory important in creating a unique experience and delight to the audiences.

\section{ii. Affective}

Affective dimension refers to feelings or sentiment (emotion) that evoke through brand (Wood, 2000; Ong, Lee and Ramayah, 2018). Emotions are the impulses of reaction to external and internal stimuli from individuals (Amanah and Purba, 2012). Cole, Martin and Dennis (2004) explain that emotions are moving targets that invisible (feeling or thoughts) and can be inferred from individual relation to surrounding events, next tend toward action. Affective/ emotional brand experience is becoming a marketing trend nowadays because it attracts its attention. Strong emotional influence can tend to the audience to have more drainage to get information about a brand. Affective brand experience can be an effective tactic in marketing: creative industry, trade and tourism in contact with the audience. 


\section{iii. Cognitive}

Cognitive involves the level and process of a person's thinking, influenced by the experience or situation around them. According to Fraser health (2020), cognitive or intellectual development is the growth of the ability to think about how individuals organise their thoughts or ideas, evaluate and consider an event. A cognitive behavioural approach is a form that helps to have a satisfying experience, can adapt to the surrounding lifestyle as well as help individuals to avoid stress and always think positively. Rahmi (2015) explain in their research that where perceptions, thoughts, beliefs are considered cognitive, the pattern of the previous behavioural approach is stimulus-response, then in cognitive behaviour, it becomes stimulus $\rightarrow$ cognition $\rightarrow$ response. Cognitive can increase an individual's confidence and trust before reacting to something or making a decision.

\section{iv. Behavioural}

Each user interaction with the brand determines brand experience regarding price, quality, products, services, premises, logos and everything related to the brand. Brand-generated experience can affect consumers' senses, behaviour, affective and cognitive. Behaviour determines the quality of a brand experience. Behavioural brand experience is related to bodily experience (Kumar and Kaushik, 2017), leading to an action (Ong et al., 2018). Behaviour has a positive influence on brand loyalty (Brakus et al., 2009).

\section{B. Brand Personality}

According to Allport (1971), personality is fundamental in an individual that can nurture his behavioural and thought characteristics; he stated that human behaviour is controlled by internal factors where different behaviours are due to opposite inclinations or traits. Youshan and Hassan (2015) stated that personality is a set of dynamic traits that a person influences cognitive, motivation, and behaviour in various situations. Personality determines a person's thoughts and behaviour; it is also seen as something unique and distinguishes it from others. Brand personality conveys through various sources (Boga and Weiermair, 2011). A person distinguishes by his personality and character and the brand, where the brand requires a different personality from the competitor brand. The existence of a brand will add meaning to themselves and their lives through their status as partners or consumers (Caprara, Guido and Barbaranelli, 2001). Previous research studies on personality have produced various personality theories that can help researchers observe and explain various aspects of personality. Some theorists prefer to view personality as a unified whole, while others focus on specific traits. Personality can help companies identify targeted audiences that fit the brand being released. In addition, personality factors are often used in other fields such as education, organisational (Shah and Halim, 2018) and in measuring the pure values of employees (Ayop et al., 2014).

We can see each brand has its personality, creating a personality that suits its target audience. This requirement is vital to create comfort and enjoyment in the audience while trying, owning and using the brand like the Nike brand, which produces a wide variety of styles, colours and special functions in their products such as shoes, shirts and other items which are likely to match the character of their target audiences. In addition, McDonald's brand also has a good production of brand personality; each production is by its brand's location. For example, McDonald's in India, the Big Mac menu is modified with a local characteristic that does not contain beef. The festival also has its brand personality. It is an attraction to gather the audience like the Rainforest Music Festival, which brings together world-renowned 
musicians from the interiors of the mythical of Borneo and provides a variety of services and products based on Sarawak art. Each brand has its way of showcasing its brand personality. To create delight in the audience is easy if following the proper flow and strategy.

Aaker (1997) is one of the most famous researchers related to brand personality research in the scope of brand personality. He defined that brand personality as " a set of human characteristic associated with the brand". He has released several scales to measure brand personality with the audience. Several previous researchers have used personality dimensions to review their studies in terms of products, services and education (Freling and Forbes, 2005; Chen and Phou, 2013; Rutter, Lettice and Nadeau, 2016; Hudson, Roth, Madden and Hudson, 2015; Choi, Ok, and Hyun, 2017).

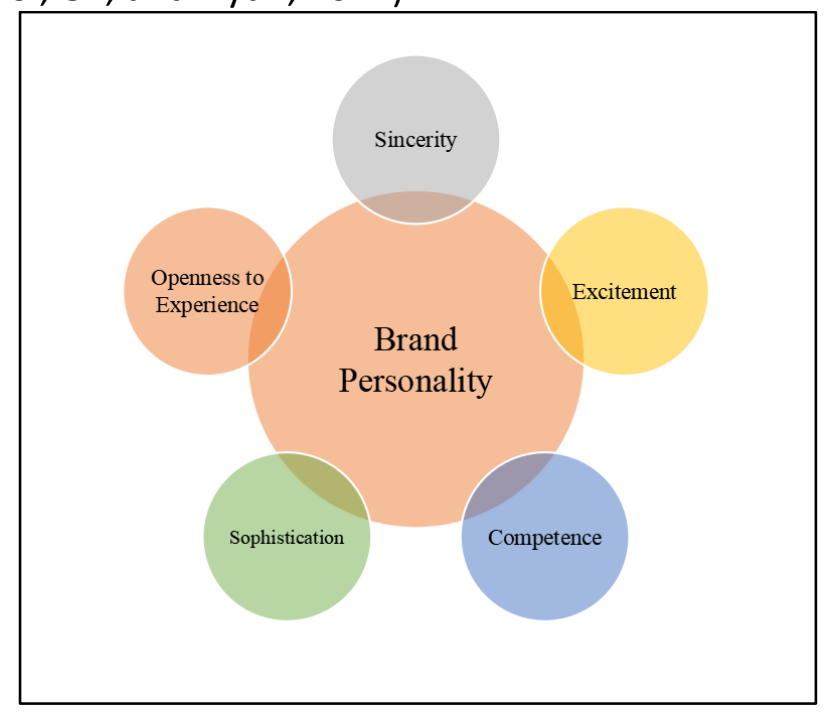

Figure 2: Item of Moderator Variable

Sources: Peco, Polo and Fries (2020)

Peco, Polo and Fries (2020) used an exploratory approach to measure the brand personality scale by Aaker (1997) and Goldberg (1993) (figure 4) and adapted it to their research needs on cultural tourism. There are five appropriate scales used to identify the relationship of the variables carried out. Among the five scales that have been adapted in Peco, Polo and Fries (2020), namely sincerity, excitement, competence, sophistication and openness to experience.

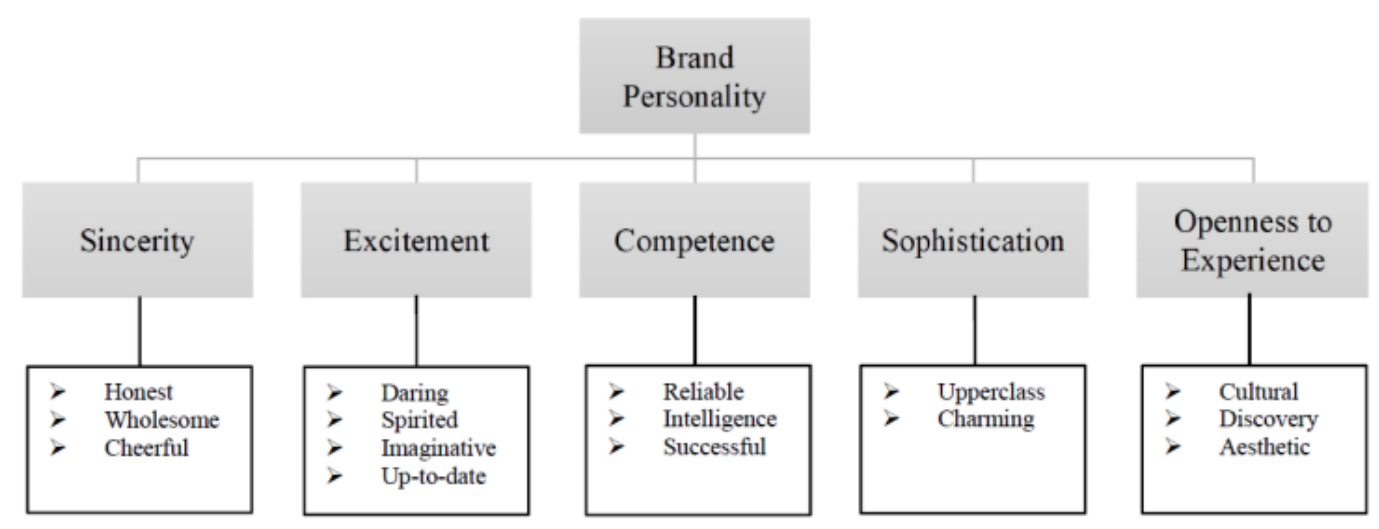

Figure 3: A Brand Personality Framework

Each scale in their brand personality is divided into several facets, while each facet produced consists of several parts that make it easier for researchers to describe the brand personality 
related to the audience. Sincerity consists of honesty, wholesome, and cheerfulness; Excitement includes online, spirited, imaginative and up-to-date; Competence is reliable, intelligent and successful; Sophistication is divided into the upper class and charming; while openness to experience is divided into three aspects, namely cultural, discovery and aesthetic.

The brand personality scale and framework need to be developed and researched to obtain new theories and views on the antecedence and consequences of the brand personality according to each required sector, such as tourism, product, services, learning development, employment, and other sectors. Brand personality is vital for the company and buyer, employees and stakeholder in further developing more advanced brands.

\section{Delight}

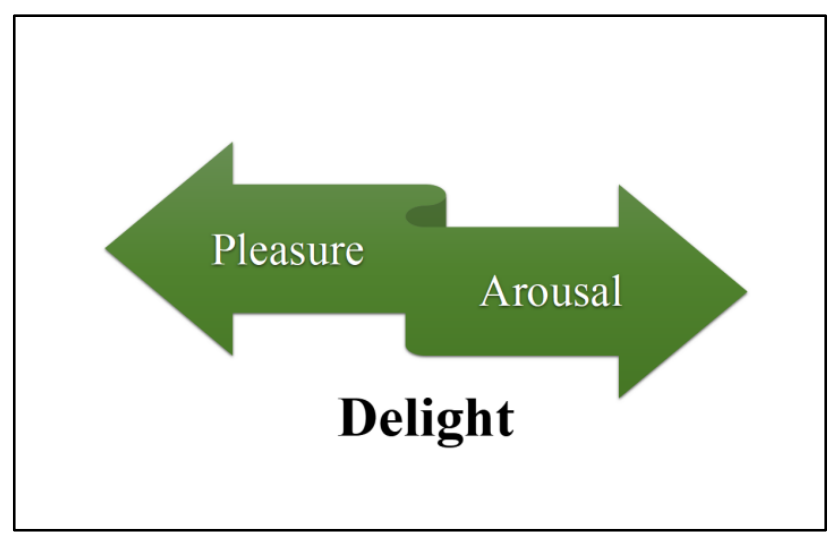

Figure 4: Item of Dependent Variables

Sources: Finn (2005); Loureiro (2010)

Finn (2005) defined delight as an emotional response resulting from a surprising and positive achievement level. Delight positively affects audience loyalty compared to satisfaction (Loureiro, 2010; Torres and Kline, 2006; Kim, Vogt, and Knutson, 2015; Ahrholdt, Gudergan, and Ringle, 2016). Even satisfaction has significant to loyalty; the delight is beyond satisfaction. According to Plutchik (1980), delight is different from satisfaction, where delight is an emotion and satisfaction is a combination of emotions and cognition (cited in Kim, Vogt and Knutson, 2015). Emotions generally have two dimensions, namely pleasure and arousal. Pleasure refers to feeling joyful and happy, while arousal refers to how a person is stimulated and active such as surprise. 


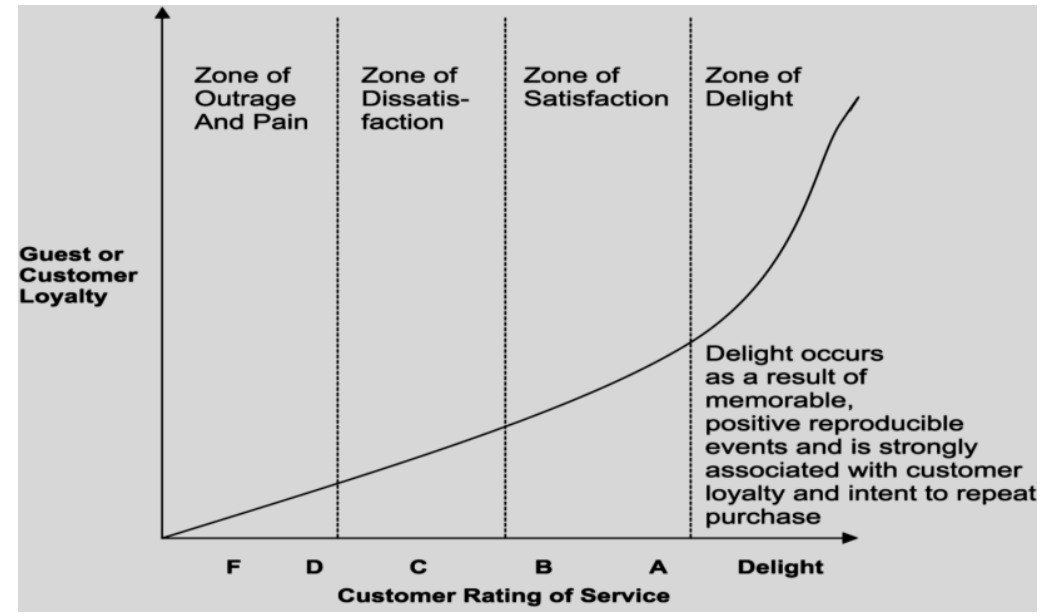

Figure 5: Zone of Outrage and Pain, Dissatisfaction, Satisfaction, and Delight. Source: Berman (2005)

Berman (2005) has proposed a model of delight scale to see the difference in the level of audience satisfaction and delight. Outrage and pain reactions are expected to occur when the audience receives poor treatment and negatively disturbs the audiences' emotions. The second stage is dissatisfaction, where it occurs when the services or products provided do not meet audience expectations. When audience expectations are met, they will feel satisfied and likely to repeat the purchase. In this model, delight is the highest level where it exceeds the level of satisfaction. Delight is a combination of surprise and happiness. It will happen to the audience when the product or service obtained exceeds the expectations offered. This is more likely to produce positive responses such as word of mouth, repurchase intention and loyalty. Delighting the audience needs to be considered comprehensively in the purchase context. As long as it involves the audience and the exchange with each other, delight should be given priority. Referring to the study of Chiu, Sheng and Tsung (2016), delight is considered as an indicator for audience relationship management in the hotel industry. Organisational culture plays an essential role in providing audience delight. Chiu, Sheng, and Tsung (2016) have developed this study by producing a framework on audience delight cultural to be understood more clearly.

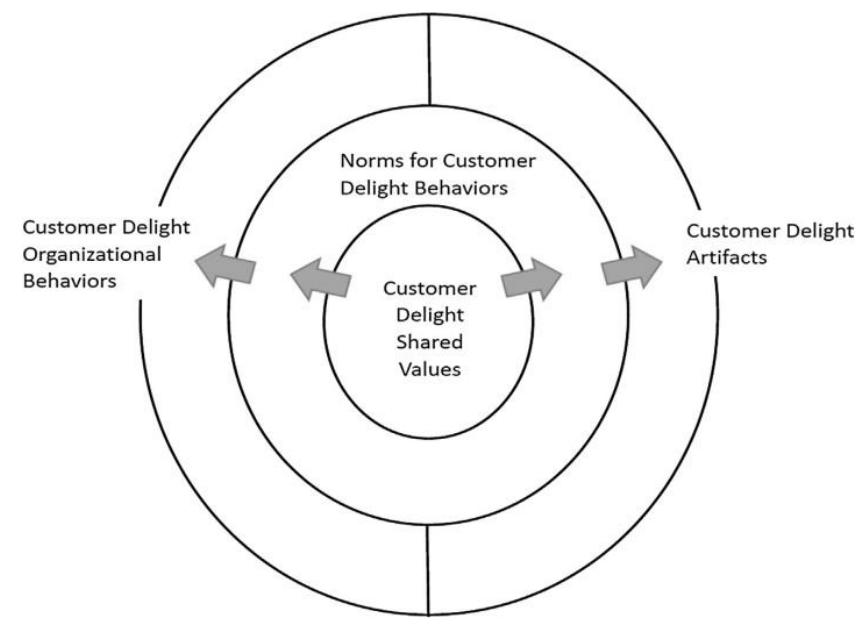

Figure 6: The Interrelation of customers delight cultural layer. Sources: Chiu, Sheng, and Tsung (2016) 
Every aspect in the customers delights cultural layer has the importance and duties outlined to meet the customer's pleasure. According to Chiu, Shen, and Tsung (2016), three customer delight values were identified in their study: customers orientated value, services innovation value, and services quality value. Every current value, such as think before the customer, providing positive surprise services, and pursuing service competencies, needs to be inculcated in the organisational culture to create joy.

While in customer delight artefacts, there are three other parts: superior service environment, customers delight service scripting, and ritual design. This section explains that organisations need visual and audio devices to create customers delight, show positive body language and ethics to apply a unique atmosphere and often hold special ceremonies to create an unforgettable experience for the audience.

Norms of customer delight behaviour also have their part applied in the culture layer of delight. Norms for customers delight: customer-oriented norms, customers delight competencies, and communication norms. Understanding each customer's needs and wants, solving their problems, and sharing information about the offer is an effective organisational culture strategy for influencing customers. The last customers delight cultural layer related to organisational behaviour, consisting of competencies development, employee development, and service quality control system. All these parts are a key that is considered necessary in customer delight.

Every organisation should use every facet developed in the delight cultural layer to create pleasure in the right way for the customer. Effects of delight can also help the audience motivate the community to get involved in a brand.

\section{Result of New Conceptual Framework}

The research framework that has been formed will guide researchers in researching audience delight. In addition, the formation of this research framework can help construct the research hypothesis and ensure that the requirements of the study are met. There are three variables focused on in this study; each variable has elements that can reinforce it. There are three variables in the framework of this study; dependent variables, independent variables and moderation variables. These three variables have their dimensions and scales to facilitate researchers to obtain accurate and relevant research results. Brand experience, brand personality and excitement have been developed and used by several past researchers related to product brands (Brakus, Schmitt, and Zarantonello, 2009; Iglesias, Singh, Batista, 2010;), fashion (Kim, 2012), restaurants, hotels (Khan and Rahman, 2016; Ong, Lee and Ramayah, 2018) and quality of service (Nyveen, Pedersan and Skard, 2012).

Independent variable refers to brand experience, consisting of 4 items; sensory, affective, behaviour, and cognitive. Organisations need to be wised to put anything brand-related in their minds. Every audience engagement in a brand is related to experience. According to Brakus, Schmitt and Zaratonello (2009), an organisation needs to focus on stakeholder experiences. All forms of stimuli such as background, slogan, brand character, environment, communication and marketing should be given attention because it helps create a long-term experience. In the context of a virtual festival, the measurement of audience experience will be studied and observed because virtual and physical have significant differences that can affect the audience experience. Experience is a component where the brand binds the audience. 


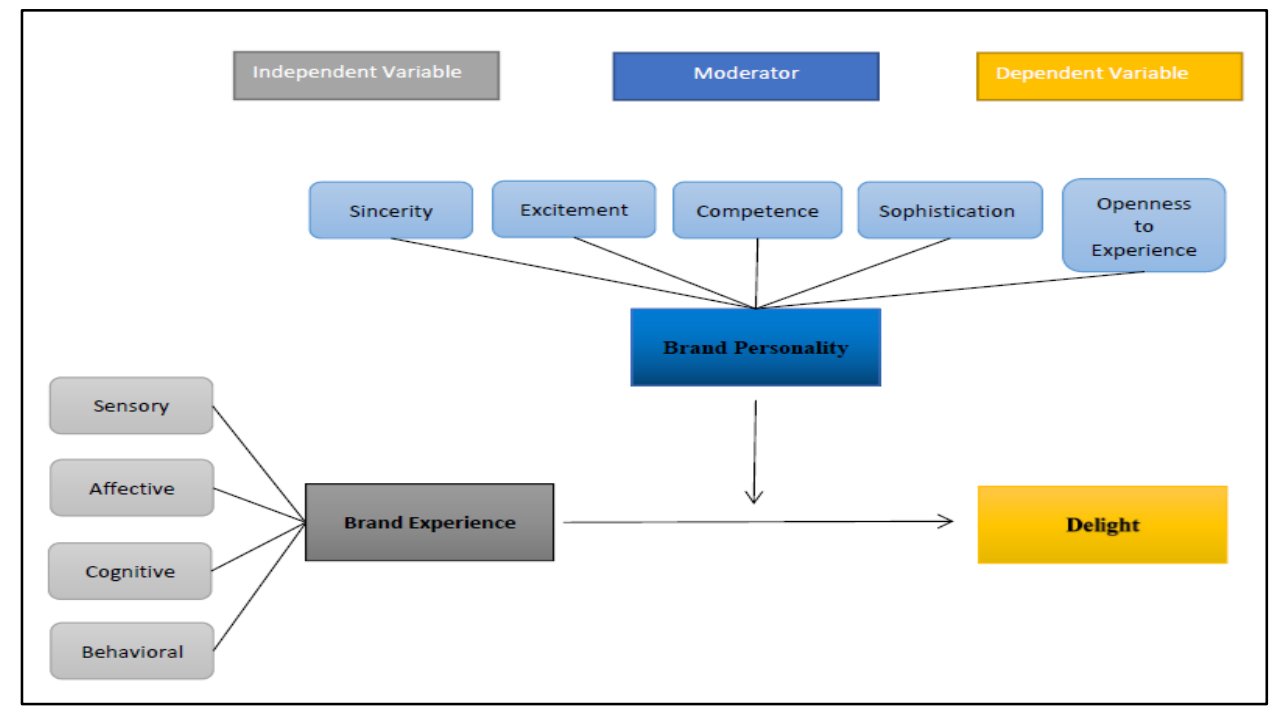

Figure 7: New Framework

The concept of brand experience encompasses sensory dimensions that refer to the visual, auditory, tactile, gustative, and olfactory provided by the brand. The affective dimension is associated with the feelings produced by the brand and relates to the audience's emotions, while the cognitive dimension refers to the brand's ability to involve the audience's concentration and thinking. The last dimension is the dimension of behaviour that brings the audience's interaction with the brand that encompasses body or lifestyle experiences. The brand experience does not involve the product or service alone; it involves the entire organisational concerning quality, service and promise were given to the audience. All of this affects the audience's experience with the brand. If the accepted brand meets and exceeds their expectations, it will positively affect the revisit intention. Overall, the content in this brand experience will ensure that the festival organisation offers an exciting and unique experience to the audience.

For the involvement of brand experience in the context of virtual festivals, researchers argue that every event organiser should give priority to improving the production and quality of performances in terms of performance image (visual) and music rhythm (audio) to create excitement in the audience given that the other three components namely touch, smell and taste cannot be felt during virtual.

Brand personality is placed as a moderator variable in this conceptual framework. One way to realise a satisfactory level of delight is to adapt the brand's personality to the audience's personality. The Brand personality refers to human characteristics which distinguish a brand. Brand personality persistently spots target audiences and simplify marketing methods. There are five dimensions in a brand: sincerity, excitement, competence, and sophistication personality. The characteristics of the art festival must be further observed because it includes elements specific to different kinds of resources from the initial scale of Aaker (1997) in a measure of the brand personality. Delight used as a dependent variable in this conceptual framework. Delight has become a priority nowadays to build confidence in the produced and presented brands. Audience delight represents a definite competitive advantage for an organisation. Each variable closely links to each other to delight potential consumers. 


\section{Conclusion}

This study found that the influence of brand experience has a significant impact on an organisation. Each dimension of the brand experience will affect the brand loyalty of the audience differently. Several previous researchers have tested the brand experience measurement developed by Brakus, Schmitt, and Zarantonello (2009) in different contexts (Ong, Lee, \& Ramanayah, 2018; Nysveen, Pedersen, \& Skard, 2013); Iglesias, Singh, \& Batista Foguet, 2011). Brand personality development in Aaker's (1997) study also has received attention from other researchers. The previous researcher has established different scales and personality traits based on the study sector (Guens, Weijters \& Wulf, 2009; d'Astous and Colbert, 2006; Smith, 2009; Tong, 2015, Peco, Polo and Fries, 2020).

The critical constructs developed to audience delight are brand experience and personality. Brand experience has behavioural effects that lead to satisfaction, loyalty through brand personality (Brakus, Schmitt \& Zarantonelli, 2009) and on brand prestige directly (Choi, Ok \& Hyun, 2017). The delight construct in this new concept is created because it is seen as an element that is more effective and different from satisfaction. Berman (2005) states that satisfaction is seen as far as the target exceeds set expectations. In contrast, delight is an unexpected, positive, and more effective target outcome. The use construct of delight in previous festivals has been less focused. Therefore, researchers developed this model to see how brand experience and brand personality lead to audience delight.

This model (refer to Figure 7) is suitable to be applied by organisations, companies, and individuals involved in brand development and audience engagement. Researchers highlighted the construction of experience and personality brand because they are the basis for establishing relationships and interactions with the audience. For future studies, researchers are proposing to construct delight connections to validate the impact on the development of delight in the festival brand, such as loyalty, word of mouth, revisit intention, willingness to pay, etc.

\section{References}

Aaker, J. L. (1997), "Dimension of brand personality," Journal of Marketing Research, 34, 347 56.

Ahn, J., \& Joon, B. K. (2018) Beyond gambling: mediating roles of brand experience and attitude, International Journal of Contemporary Hospitality Management, 30(10)30263039.

Ahrholdt, D. C., Gurdegan, S. P., \& Ringle, C. M. (2016) Enhancing service loyalty: The roles of delight, satisfaction, and services quality. Journal of Travel Research, 1-15.

Allport, G. W. (1971) Personality : A psychological interpretation. London : Redwood Press Limited.

Ayop, S. R., Halim, F. W., Ahmand, M. I., \& Zukepli, Z. (2014). Personaliti lima faktor: Pengaruhnya terhadap nilai peribadi asas dalam kalangan Pegawai Tadbir Diplomatik. Seminar Psikologi Malaysia, Universiti Pendidikan Sultan Idris.

Amanah, D., \& Purba, A. F. (2012). Pengaruh produk dan faktor emosional konsumen terhadap keputusan pembelian sepeda motor Yamaha (Studi kasus pada mahasiswa fakultas ekonomi UNIMED). Jurnal Niagawan, 1 (1), 45-54.

Berman, B. (2005). How to delight your customers. California Management Review, 48(1), 129-151. 
Brakus, J. J., Schmitt, B., \& Zarantello, L. (2009). Brand experience: what is it? How is it measured? Does it affect loyalty?. Journal of Marketing, 73(3), 52-68

Berridge, G. (2011). Events design and experience. Routledge.

Caprara, G. V., Guido, G., \& Barbaranelli, C. (2001). Brand personality: How to fit it?. Journal of Economic Psychology, 22, 377-395.

Chaney, D., Lunardo, R., \& Mencarelli, R. ( 2018). Consumption experience: Past, present and future. Qualitative Market Research, 1-37

Chen, C. F., \& Phou, S. (2013). A closer look at destination: Image, personality, relationship and loyalty. Tourism Management, 36, 269-278.

Chernatony, L. D. (2010). From brand vision to brand evaluation ( $3^{\text {rd }}$ ed.). Thomson.

Chernev, A. (2017) Strategic brand management ( $2^{\text {nd }}$ ed.). Cerebellum Press.

Choi, Y. G., Ok, C., Michael, \& Hyun, S. S. (2017). Relationships between brand experiences, personality traits, prestige, relationship quality, and loyalty. International Journal of Contemporary Hospitality Management, 29(4), 1185-1202.

Chiu, K. Y., Sheng, H. T., \& Tsung, C. W. (2016). Organizational culture on customer delight in the hospitality industry. International Journal of Hospitality Management, 56, 98-108.

Finn, A. (2005). Reassessing the foundations of customer delight. Journal of Service Research, 8(2), 103-116.

Freling, T. H., \& Forbes, L. P. (2005), An empirical analysis of the brand personality effect, Journal of Product \& Brand Management,14(7), 404-413.

Geuens, M., Weijters, B., \& Wulf, K. D. (2009). A new measure of brand personality. International Journal of Research in Marketing, 26(2), 97-107.

Hudson, S., Roth, M. S., Madden, T. J., \& Hudson, R. (2015). The effects of social media on emotions, brand relationship quality, and word of mouth: An empirical study of music festival attendees. Tourism Management, 47, 68-76.

Hulten, B. (2011). Sensory marketing: the multi-sensory brand-experience concept. European Business Review, 23(3), 256-273.

Iglesias, O., Singh, J. J., \& Batista Foguet, J. M. (2011). The role of brand experience and affective commitment in determining brand loyalty. Journal of Brand Management, 18(8), 570-582.

Kim, M., Vogt, C. A., \& Knutson, B. J. (2015). Relationships among customer satisfaction, delight, and loyalty in the hospitality industry. Journal of Hospitality \& Tourism Research, 39(2), 170-197.

Kumar, V., \& Kaushik, A. K. (2017). Destination brand experience and visitor behavior: the mediating role of destination brand identification. Journal of Travel and Tourism Marketing, 1-14.

Loureiro, S. M. C. (2010). Satisfying and delighting the rural tourists. Journal of Travel \& Tourism Marketing, 27(4), 396-408.

Meyer, T., Barnes, D. C., \& Friend, S. B. (2017). The role of delight in driving repurchase intentions. Journal of Personal Selling \& Sales Management, 1-11.

Nilsson, L. (2020). Hybrid event: Breaking the boarder. LAB University Applied Science.

Nysveen, H., Pedersen, P. E., \& Skard, S. (2012). Brand experiences in service organizations: Exploring the individual effect of brand experience dimension. Journal of Brand Management, 20(5), 404-423.

Ong, C. H., Lee, H. W., \& Ramayah, T. (2018). Impact of brand experience on loyalty. Journal of Hospitality Marketing \& Management, 27(7), 755-774. 
Peco, T. F., Polo, P. A. I., \& Frias, J. D.M. (2020). Brand personality in cultural tourism through social media. Tourism Review.

Rahmi, S. (2015). Pengaruh pendekatan prilaku kognitif terhadap tingkat penyesuaian diri siswa di kelas vii SMP negeri 29 Makassar. Jurnal Psikologi Pendidikan \& Konseling, (1)1, 28-38.

Rutter, R., Lettice, F., \& Nadeau, J. (2016). Brand personality in higher education: anthropomorphize university marketing communications. Journal of Marketing Higher Education, 1-21.

Shah, N. F. M., \& Halim, F. W. (2018). The Influence of the five factor personality upon organisational citizenship behaviour (OCB) among teachers. Jurnal Psikologi Malaysia, (32)2, 136-147.

Smith, G. (2009). Conceptualizing and testing brand personality in British politics. Journal of Political Marketing, 8(3), 209-232

Torres, E. N., and Kline, S. (2006), "From customer satisfaction to delight: a model for the hotel industry", International Journal of Contemporary Hospitality Management, 18(4), 290-301.

Torres, E. N., \& Kline, S. (2013). "From customer satisfaction to customer delight: Creating a new standard of service for the hotel industry". International Journal of Contemporary Hospitality Management, 25(5),642-65. 